\title{
PAULO FREIRE, O TESTEMUNHO E A PEDAGOGIA CATÓLICA A ação histórica contra o fatalismo*
}

\section{Eduardo Dullo}

O meu discurso em favor do sonho, da utopia, da liberdade, da democracia é o discurso de quem recusa a acomodação e não deixa morrer em si o gosto de ser gente, que o fatalismo deteriora.

Paulo Freire (2001, p. 86).

Uma problemática das mais importantes no trabalho de Paulo Freire é o fatalismo. Por isso, a sua proposta pedagógica visa à promoção de seu oposto: a ação do sujeito em seu contexto, a per-

* Uma versão anterior deste texto foi apresentada no Seminário Aberto do Etno-história (DA/USP) e compõe o primeiro capítulo de minha tese (Dullo 2013). Agradeço a Lilia Schwarcz e André Botelho pelas críticas e sugestóes no evento, bem como a todo o grupo de pesquisa pelo diálogo posterior. Agradeço também aos pareceristas anônimos pelas sugestôes de melhorias. Os erros não sanados são de minha inteira responsabilidade.

Artigo recebido em 03/04/2012

Aprovado em 07/02/2014 cepção de que é possível e necessário agir para mudar o mundo. O presente texto pretende apresentar a questão a partir de um ângulo específico: reconhecendo a relevância do testemunho para a estrutura da pedagogia de Freire, irei mimetizar o seu tom reverencial no início do meu texto. $\mathrm{O}$ testemunho, como retórica cristã, apresenta uma experiência pessoal ao interlocutor de modo a provocar neste uma identificação e transformação interior. É uma fala não apenas informativa, mas performativa. $\mathrm{O}$ testemunho pode ser entendido, portanto, como um ato de fala (ou de escrita), capaz de articular uma experiência de verdade para uma audiência/público. No caso de Freire, a experiência narrada envolve a de sua participação na pobreza e nas dificuldades dos oprimidos. A verdade é o seu diagnóstico do Brasil e o público desejado é composto pelos oprimidos a serem libertados e pelos educadores e agentes sociais que irão trabalhar por essa transformação social. 
Veremos, ao longo do texto, que sua proposta pedagógica situa-se para além da definição das fronteiras do que é "religião", "política" ou "educação". Sigo, nesse sentido, uma posição antiessencialista e de definições historicamente situadas a partir dos enunciados mobilizados pelos agentes (Asad, 2010). O trabalho de Freire é relevante por ser exemplar de um movimento pouco explorado nas ciências sociais quando se trata da "secularização": não o movimento do Estado que define e legisla sobre o que é a religião e como ela deve portar-se na sociedade, postura adotada como "natural" pela teoria (Taylor, 2007; Dullo, 2012), mas como os membros religiosos envolveram-se na articulação entre o secular e o religioso, produzindo sua própria "secularização" (Casanova, 2011, p. 56), isto é, a preocupação de insuflar o religioso no mundo. Para esse sentido específico de "secularização", sugiro, entretanto, outro termo: mundanização. ${ }^{1}$ Assim, veremos como Paulo Freire é exemplar de uma das correntes católicas que se desenvolveram a partir dos anos de 1950 no Brasil, visando, justamente, realizar esta tarefa: a de trazer os sujeitos como cristãos e enquanto cristãos para o mundano, com o objetivo de transformá-lo por meio da presença recristianizadora.

\section{A narrativa}

Em todas as ocasiões em que Paulo Freire fala contra o fatalismo, ele assume um tom intenso, reverencial, apaixonado - é o discurso de alguém que não se deixou morrer, de quem escolheu a vida, ou melhor, o renascimento. $\mathrm{O}$ uso dessas palavras não é vão. Como apresentarei a seguir, é com base em uma gramática cristã e em sua fé católica que o educador se posiciona para retransmitir essa experiência e transformar seus interlocutores em sujeitos, isto é, em indivíduos capazes de se reconhecer como agentes no curso da história e, portanto, responsáveis por ele.

Nascido em Recife, em 1921, Paulo Freire cresceu em uma família relativamente simples e que contava com auxílio financeiro de um parente bem-sucedido, dono de pequeno comércio no Rio de Janeiro. Sua trajetória, entretanto, sofreria dois reveses: a crise de 1929 afetou o comércio, que faliu; seu pai, o "capitão Temístocles", faleceu. A mãe, católica piedosa, viu-se em dificuldades para sustentar a si e aos filhos. O pequeno Paulo perambulava com ela de venda em venda, procurando um local em que conseguissem comprar, fiado, a comida. Ela não perdeu, porém, sua fé (em Deus e nos homens) e procurou meios e alternativas para, além de tudo, fazê-los estudar. O difícil período da infância de Freire é relembrado por ele numa espécie de "autobiografia": ${ }^{2}$ Cartas a Cristina: reflexōes sobre minha vida e minha práxis (2003a). Em situações como essa, de desalento, muitas pessoas deixam-se cair, sem vislumbrar possibilidades de ação. É essa experiência, bastante concreta e sentida na carne, que Paulo Freire traz à tona e procura transmitir quando faz seu discurso contra o fatalismo.

Talvez seja esta uma das positividades da negatividade do contexto real em que minha família se moveu:

1) o de, experimentando-me na carência, não ter caído no fatalismo;

2) o de, nascido numa família de formação cristã, não ter me orientado no sentido de aceitar a situação como sendo a expressão da vontade de Deus, entendendo, pelo contrário, que havia algo errado no mundo e que este precisava de reparo (Freire, 2003a, p. 38).

Acreditando em seus sonhos, Freire narra como prosseguiu na batalha da vida a ponto de conseguir estudar, por meio do auxílio do dono de um dos melhores colégios do Recife no final dos anos de 1930 e início da década seguinte, no Colégio Oswaldo Cruz (COC). Mais tarde retornou ao colégio como professor de língua portuguesa, além de ingressar na Faculdade de Direito, em que se bacharelou em 1947. Foi nesse mesmo ano, depois de uma experiência frustrada na advocacia, em que não se sentiu capaz de realizar a cobrança a um dentista pai de família, em que deveria retirar os seus instrumentos de trabalho, que se tornou funcionário no Sesi e iniciou sua prática pedagógica, ainda não elaborada teoricamente, tal como a conhecemos. 
Esse percurso inicial de sua trajetória é continuamente lembrado e utilizado estrategicamente para demonstrar ao seu interlocutor como a sua experiência lhe marcou, a ponto de provocar nele uma ruptura e uma conversão. $\mathrm{O}$ relativo sucesso não apagou de sua memória a experiência do sofrimento. Pelo contrário, fez com que ele aderisse à luta pela libertação dos oprimidos e testemunhasse a possibilidade do sonho de um mundo mais justo.

O livro Pedagogia do oprimido (escrito em $1967-$ 1968, durante exílio no Chile), considerada sua mais importante obra, reflete em algumas páginas acerca "de um problema de importância inegável": "a adesão e consequente passagem que fazem representantes do polo opressor ao polo dos oprimidos" (2005, p. 53), uma "passagem" que ele mesmo teria feito. Nessa reflexão mostra-se contrário aos que pretendem dirigir o "povo", comandá-lo e ensiná-lo, aos que se colocam em posição de superioridade e se consideram "revolucionários". É preciso "humildade", afirma Freire, para aprender com o povo e ser capaz de "comungar" com ele, evitando certa nostalgia de sua origem (Idem, p. 54). É assim que ele solicita aos que o ouvem (ou leem) que também deixem essa vida injusta, autoritária, machista, racista e renasçam como novas pessoas.

Não há sombra de dúvida de que a fim de o professor racista, de o professor machista, de o professor elitista, que falam de democracia e se dizem progressistas, poderem realmente comprometer-se com a liberdade, é preciso que façam a sua "páscoa": que "morram" como $m a$ chista, como racista, como elitista para "renascer" como verdadeiros progressistas, inscritos na luta de reinvenção do mundo (2003a, p. 212 , grifos originais).

Além da experiência que lhe possibilitou a passagem da conversão, a estratégia assumida por Freire é também cristã: a prática do testemunho aparece como sua maneira de evangelizar, de anunciar a boa nova. "O testemunho, na teoria dialógica da ação, é uma das conotaçôes principais do caráter cultural e pedagógico da revolução" (2005, p. 203) e, sendo "ousado e amoroso, serve à organização" (Idem, p. 204). O testemunho, na medida em que é anún- cio, é, inicialmente, narrativa de uma vida pregressa, marcada pela malignidade, e da transformação ocorrida, capaz de salvar. No cristianismo, essa prática narrativa é bastante antiga, estando presente, por exemplo, nas Confissóes de Santo Agostinho. As maneiras pelas quais é possível enunciar religiosamente a verdade variam de acordo com algumas diretivas e, poderíamos diferenciar a prédica da confissão e, estas, do testemunho, do louvor e de tantas outras. A especificidade da forma narrativa do testemunho em relação à confissão é a de que não se visa redimir-se de um pecado cometido, tendo, como destinatário da narrativa, Deus ou algum mediador. No caso do testemunho, a transformação já foi operada, o pecado já é percebido como perdoado e, então, testemunha-se essa mesma transformação com o intuito de afirmá-la para outros sujeitos, e não para Deus. Assim, ao confessar seus pecados juvenis para seus leitores, Santo Agostinho presta testemunho da transformação operada por Deus. ${ }^{3}$ Como argumenta Hannah Arendt,

Agostinho, porém, olha para sua vida não para glorificar a si mesmo, e sim a Deus. [...] No momento da conversão, Agostinho foi redimido por Deus - não o mundo todo, mas apenas ele, Agostinho, que se pôs diante de Deus. Foi redimido de sua vida pecaminosa, e o fato de se confessar para essa redenção resulta na glória de Deus e é um testemunho humano do poder divino. Nessa confissão, ele deve relembrar toda a sua vida anterior, e na verdade cada pedacinho de sua vida anterior, porque todos os momentos dessa vida foram pecaminosos e, portanto, cada um deles engrandece o poder e o milagre da redenção (2008, p. 55).

Há duas diferenças, cruciais, entre as Confissões de Santo Agostinho e a narrativa de Paulo Freire. Uma está na crescente preocupação com a transformação do mundo pelo catolicismo, tal como ocorre na metade do século XX, principalmente após o Concílio Vaticano II. Não é por menos que o breve e impressionante texto de Arendt reivindica Agostinho (sem o epíteto de Santo) para o protestantismo, pois ela enfatizará algo que foi também sublinhado por Weber (1982, p. 228) em seus estudos 
sobre o cristianismo protestante e o capitalismo: a transformação operada por Deus visa controlar ou eliminar a malignidade interna ao indivíduo. A outra diferença diz respeito à menor visibilidade da ação de Deus no mundo (inexistente na narrativa de Freire) e uma maior necessidade de ação humana. Por essas duas razões, o testemunho de Freire, em consonância com correntes de teologia católica dos anos de 1950 (Azzi, 2008, p. 420), é voltado para o exterior (de si), isto é, para a denúncia da malignidade do mundo e para o anúncio da possibilidade de lutar contra ela (Freire, 1979a, p. 111); ou seja, seu testemunho é uma estratégia narrativa para a transmissão da experiência (Benjamin, 1994a) que o fez sair da consciência "ingênua" rumo à "crítica”, o que envolve ver, julgar e agir no mundo.

Tendo entendido essa estrutura retórica testemunhal básica de sua "obra" (Faria, 2002, p. 34), ou nos termos de Foucault, sua "função de expressão", ${ }^{4}$ e seu caráter estratégico, podemos retornar às duas experiências que Freire indicou em suas Cartas como capazes de gerar o fatalismo e que são, portanto, objeto da denúncia: a visão distorcida de Deus e a ordem social injusta.

\section{A visão distorcida de Deus}

A crítica de Paulo Freire é contra qualquer religião (não só a Igreja Católica) que separa a transcendência da mundanidade, coloca Deus fora da realidade, condenando esta última a ser o resultado da vontade Dele e, por consequência, como essencialmente correta e contra a qual é pecado se insurgir (Freire, 2005, p. 55). Este aspecto, acredito, é a reverberação de diversas leituras feitas ainda em seu "período de formação", como pude constatar com base na pesquisa em seu arquivo. ${ }^{5} \mathrm{O}$ livro de Nicolas Berdiaeff (El cristianismo y el problema del comunismo) trazia grifos na seguinte passagem da página 43:

A religião em geral, e o Cristianismo em particular, despreza a atividade humana, prega o estado passivo, a submissão ao destino, a resignação frente à injustiça social e ensina a entregar-se à vontade de Deus para tudo, jus- tificando desta maneira a opressão do homem por seu semelhante. Parece que, de acordo com a religião cristã, só Deus é ativo e que a única preocupação do homem é rezar, resignar-se, cantar Te Deums e esperar que lhe chegue a Graça (tradução minha).

Com isso não se está questionando a existência de Deus, mas a posição dos que doutrinam. O próprio livro de Berdiaeff é escrito para desqualificar o comunismo como alternativa, tendo o mérito de mostrá-lo, apesar de tudo, como positivo por tornar claro aos cristãos que não é possível permanecer na injustiça do mundo. Como me atestou Lutgardes Freire, o filho caçula, em uma conversa no Instituto Paulo Freire (IPF), Paulo permaneceu católico mesmo quando discordava da posição política reacionária da Igreja. Em seu exílio no Chile, incomodado com o apoio da Igreja com práticas autoritárias, fez com que a família deixasse de frequentar as missas aos domingos e solicitou a um amigo, padre, que rezasse a missa em sua residência, para a família. Assim, a crítica não é dirigida ao cristianismo em si, mas aos cristãos e às consequências de sua fé.

Para compreendermos melhor essa crítica, é necessário nos determos no cenário brasileiro de então. Dom Leme (bispo, depois cardeal) aparece como motivador de grande parte dos acontecimentos posteriores. Em 1916, em Carta Pastoral de Saudação à Arquidiocese de Olinda, ele "tratara dos problemas da indiferença religiosa no Brasil, do esquema mental agnóstico, secular e positivista da maioria dos intelectuais brasileiros e da falta de fundamentação doutrinária das ideias dos que se autointitulavam católicos" (Kadt, 2003, p. 91). Ele buscava, portanto, a recuperação do poder em relação aos destinos do Estado-nação, mas isso não ocorreria, segundo ele, em uma reunião formal com a Igreja, mas por meio da crítica ao catolicismo apático e do incentivo à ação, o que seria observado tanto no desenvolvimento da intelectualidade quanto na inserção de militantes católicos nos quadros do governo. ${ }^{6}$

A Carta de dom Leme é considerada a principal responsável pela conversão de Jackson de Figueiredo, ${ }^{7}$ fundador do Centro Dom Vital em 1921 e da 
revista $A$ Ordem em $1922 .{ }^{8}$ É assim que a década de 1920 vê surgir um aglomerado de intelectuais católicos, leigos, em resposta direta à convocação feita pela hierarquia. Apesar da posição de dom Leme e de Figueiredo serem politicamente reacionárias, a favor da constituição vertical de "cima para baixo" da sociedade brasileira, este foi um momento central de organização que ficou conhecido como Restauração Católica (em que pese a influência de De Bonald e Maistre).

Com o falecimento de Figueiredo em 1928 é Alceu Amoroso Lima (pseudônimo: Tristão de Athayde) que assume a dianteira, mas não mantém a mesma posição política. Alceu foi o principal leigo católico dos anos de 1930 e 1940 (Costa, 2001), responsável pela revista A Ordem e pelo Centro Dom Vital, além de principal incentivador da Ação Católica Brasileira. Os grupos de estudo e discussão realizados no Centro Dom Vital e sob sua coordenação foram cruciais para a virada progressista que ocorreu nos anos de 1950e entre os jovens padres da época contava com figuras que posteriormente se tornariam centrais na Igreja Católica do Brasil, como o futuro arcebispo de Recife, dom Helder Câmara (Kadt, 2003, p. 93). A partir de meados da década de 1930, Amoroso Lima se aproximou da posição de Jacques Maritain e de seu Humanismo integral, a ponto de publicar uma entrevista com ele em $A$ Ordem de 1937, seguida de um artigo de sua autoria em que "separa a ação católica, ação social e ação política, para distinguir a participação dos leigos no apostolado da hierarquia eclesial, de sua função coletiva no campo social e da participação individual nos movimentos políticos" (Crochet, 2003, p. 76). Advêm de Maritain, ainda, três influências marcantes (até mesmo para a formação de Paulo Freire): a primeira e já citada é o reconhecimento da ação política dentro de uma postura católica, a segunda é a condenação dos regimes nazista e fascista e a terceira, a valorização da democracia, até então malvista pela elite conservadora católica (Azzi, 2008, pp. 517-518).

Todos esses elementos podem ser encontrados em Paulo Freire. Seu breve afastamento do catolicismo quando mais jovem cessou ao entrar em contato com o trabalho de Amoroso Lima:
Nesta época, devido às distâncias, que, ingenuamente, não podia compreender, entre a vida mesma e o compromisso que ela exige, e o que diziam os padres nos seus sermôes dominicais, afastei-me da Igreja - nunca de Deus - por um ano, com o profundo sentimento de minha mãe. Voltei a ela através, sobretudo, das sempre lembradas leituras de Tristão de Atayde, por quem, desde então, nutro inabalável admiração. A estas imediatamente se juntariam as leituras de Maritain, de Bernanos, de Mounier e outros (Freire, 1980, pp. 14-15).

A especialização da Ação Católica (AC) começa a modificar o cenário da Igreja no Brasil com a segmentação de parte importante de sua organização, qual seja, a Juventude Católica Brasileira (JCB), que passou a ter quatro segmentos: "operária", "universitária", "agrária" e "estudantil". ${ }^{9}$ Entre tais categorias, a Universitária compunha a elite acadêmica católica, cujos principais propósitos eram o aprofundamento da fé e da espiritualidade e o retorno para dentro de si e para o meio social. No decorrer dos anos, a especialização baseada em critérios sociais começa a dar sinais de esgotamento com a crítica crescente por parte dos membros da JUC. O descontentamento veio acompanhado da leitura de autores católicos, como o padre Lebret, e da discussão fomentada pela revista Esprit, dirigida por Emmanuel Mounier e lançada na França em 1932 com a proposição "personalista" que tanto influenciou o catolicismo progressista para assumir um rumo de luta pela dignidade da pessoa em detrimento do capital. Antes, esse desejo de "humanização" sempre esteve vinculado à ideia de progresso econômico nos moldes capitalistas, com base na perspectiva solidarista (Kadt, 2003, pp. 104-106).

A partir da Revolução Cubana em 1959 e com uma crescente percepção da possibilidade de agir na história, em contraposição a uma ordem social estática e imutável, sacralizada como resultante da vontade de Deus, a ascendente esquerda católica, composta principalmente por jovens universitários, radicalizou sua posição, alterando a busca por justiça fundada na assistência para a transformação das estruturas sociais, posto que a dignidade da pessoa humana não era respeitada no sistema capitalista 
(Ridenti, 2002, pp. 234-236). Tal alteração levou ao conflito com a hierarquia da Igreja, uma vez que ela se posicionava se como a mandatária dos leigos e a legitimadora de suas açōes.

Os anos de 1960 e 1961 foram decisivos para essa mudança, na medida em que os jucistas (membros da Juventude Universitária Católica - JUC) se ligaram mais estreitamente com a esquerda universitária não católica e apoiaram, juntamente com os marxistas, o mesmo candidato para a presidência da UNE. O problema para a hierarquia da Igreja Católica era a perda de controle sobre os leigos e sobre suas ideias, ou seja, a possibilidade de uma visão particular e de um pensamento próprio sobre a Igreja, o cristianismo e seu papel no mundo (Kadt, 2003, pp. 112-113).

Para os membros da JUC do Rio de Janeiro e de Minas Gerais, ${ }^{10}$ guiados intelectual e espiritualmente pelo padre Vaz, da Companhia de Jesus, a noção de "ideal histórico" transformou-se em uma perspectiva de "consciência histórica": "a concepção do homem como ser que transcende o mundo precisamente enquanto o transforma e o humaniza” (padre Vaz apud Angela Paiva, 2003, p. 178). É essa também a proposta de conscientização utilizada largamente por Paulo Freire como método, em sua luta pela "humanização" do mundo. A radicalização das posições tornou insustentável a permanência dos jucistas sob a tutela eclesiástica, obrigando os jovens a criar em 1962 um novo movimento fora dos quadros da Igreja: a Ação Popular (AP) (Ridenti, 2002, p. 238; Kadt, 2003, p. 127).

\section{Passado escravista e colonial}

O segundo elemento gerador de um sentimento fatalista em nossa sociedade é de natureza histórico-cultural: a experiência da pobreza e das dificuldades. Aqui, a análise de Paulo Freire é enriquecida pela reflexão dos autores considerados intérpretes do Brasil, permitindo a generalização da experiência: Gilberto Freyre, Francisco José de Oliveira Vianna, Caio Prado Jr., Fernando de Azevedo e os intelectuais do Instituto Superior de Estudos Brasileiros (Iseb), além de Anísio Teixeira com propostas educativas ligadas à Escola Nova. ${ }^{11}$
Freire inicia sua discussão, entretanto, a partir dos estranhamentos dos cronistas e viajantes. ${ }^{12}$ Afirma ele que todos, ou quase, estranharam o "desprezo quase mágico do nosso homem pelo trabalho manual”, isto é, uma postura arraigada "contra toda atividade que recorde a mancha desumanizante do trabalho escravo" (2003b, p. 48). O exemplo mais bem acabado dessa "disposição mental" é o senhor de engenho decadente - sobre o qual leu em Sobrados e mucambos $^{13}$ - que, uma vez rico, opulento, vaidoso, deixa-se empobrecer, mas permanece "desdenhoso de ofícios mecânicos, que abandonava a europeus e escravos" (Freyre apud Freire, 2003b, p. 50).

Embora saiba que não se trata da mesma realidade, Freire estabelece no "ontem", nas raízes de nossa formação histórico-cultural, os problemas que impedem o pleno desenvolvimento do Brasil de seu presente (Paiva, 1980, p. 89). A exploração colonial é um deles. Relatada por Gilberto Freyre como exercício do "poder do senhor", que se prolongava da terra às pessoas, e por Caio Prado Jr. como uma economia de base escravista que "não comportava uma estrutura política democrática e popular" (apud Freire, 2003b, p. 61), Paulo assinala como se fortaleceu ali o gosto pela situação de proteção, reforçada pelo "mandonismo" dos senhores que dominam suas terras e tudo que adentrá -las. Esta seria uma das raízes histórico-culturais do nosso fatalismo: a atitude de espera pela proteção de um todo poderoso com quem não há "dialogação"14 (2003b, pp. 63-64).

Outro elemento, também relacionado com o senhor de engenho, é o domínio de terras e a ausência de centros urbanos (e para isso se apoia em trechos de Oliveira Vianna). Sem experiência de vida pública, dependendo da "solidariedade privada", o "homem-massa" não chegava a se constituir em "povo". Ao contrário da situação na pólis grega, como salientada por Arendt (1989, pp. 40-42), o senhor de engenho não se constituía como cidadão. $\mathrm{Na}$ sociedade colonial escravista, como escreveu Gilberto Freyre e relembrou Araújo (1994, pp. 8586), o senhor não encontrava outros senhores no espaço comum da cidade para deliberar sobre preocupações públicas.

Além de um sistema capitalista escravista que inviabilizava a participação política -, não ha- 
via centros urbanos que propiciassem o encontro da população e o diálogo. Essas condições objetivas formavam as "disposições mentais" da população, condicionando-a à ideia de que não era possível ser mais que espectadores da história.

Se a proclamação da república foi vista por "bestificados", o golpe de 1937, acrescenta Freire seguindo Fernando de Azevedo, ocorreu "sem qualquer participação das camadas populares” (apud Freire, 2003b, p. 77). Se o passado colonial é a "raiz" de nossa "inexperiência democrática", o governo de Vargas no Estado Novo é a reafirmação do "ontem" colonial no passado recente. ${ }^{15} \mathrm{E}$ o que dizer, então, da eleição de Vargas em 1950? Para Freire, ela é a comprovação de que as "disposições mentais que criamos nestas circunstâncias foram assim disposições mentais rígidas e autoritárias" (2003b, p. 69). Ele faz referência a esta eleição numa anotação à margem do seguinte trecho do livro de Zevedei Barbu (Democracy and dictatorship: their psychology and patterns of life, 1956, p. 19):

Sempre que as pessoas em comunidade estiverem prontas para transferir o poder e a autoridade para um líder ou um partido, há uma prova evidente de que falta a eles a disposição mental democrática, mesmo quando essa transferência é feita segundo métodos impecavelmente democráticos.

Compreende-se, portanto, que é por ser resultado desse processo de formação histórica e não "um traço essencial da forma de ser do povo", cujo fatalismo seria encarado, "em análises superficiais, de docilidade, como caráter nacional" (2005, p. 55), que se faz possível e necessário combatê-lo.

Ao fatalismo e sua postura acomodada, Freire contrapõe a ação histórica. Primeiramente a sua própria, como exemplo, ao dedicar-se à educação do povo na tentativa de formar seus membros para serem homens de seu tempo: um tempo de transição. A definição de Freire para sua atualidade nos anos de 1950 é condizente com a de outros autores do período (Botelho, 2008): trata-se de uma "sociedade em movimento". As modificações nas relaçôes de trabalho, com a industrialização, e o aparecimento do povo no espaço comum, público, com a urbanização crescente, são os motivadores objetivos que se contrapõem às raízes aventadas por Freire. Sua análise é concluída pela percepção da "antinomia fundamental" (2003b, pp. 26-27): a "emersão do povo na vida pública nacional” não se concretiza devido à sua "inexperiência democrática" e ausência do "sentimento do Estado Nacional", já relatado por Oliveira Vianna.

\section{Uma pedagogia católica da ação}

Chegamos, com isso, num ponto capital: a luta contra o fatalismo é uma luta pela realização da vocação ontológica do ser humano, isto é, uma luta contra a sua "desumanização" provocada pela ordem social injusta. As relações sociais humanas, diz Freire, são prenhes de "pluralidade", "transcendência", "criticidade", "consequência" e "temporalidade" (1977, pp. 39-42), opondo-se às relações animais e à reificação do humano. $\mathrm{O}$ animal vive na unidimensionalidade da história, num eterno presente, ao qual se "acomoda" e se "ajusta", jamais se percebendo como capaz de ações consequentes, de criação e recriação do mundo (Idem, p. 43). O rebaixamento do homem a "puro objeto", por outro lado, é a consequência de ser "dominado pela força dos mitos e comandado pela publicidade organizada, ideológica ou não, e por isso vem renunciando cada vez mais, sem o saber, à sua capacidade de decidir" (Idem, ibidem).

Um dos aspectos mais relevantes para que a transformação desse mundo era fomentar nos oprimidos uma percepção da realidade que não fosse "ingênua" e, sim, "crítica". Ou seja, demandava que as pessoas não pensassem o mundo como essência, mas como processo em constante mudança: para Freire tudo está sempre "sendo", mas nunca "é". Por essa razão, um "dos aspectos mais importantes do nosso agir educativo, na fase atual de nossa história, será, sem dúvida, o de trabalhar no sentido de formar, no homem brasileiro, um especial senso, que chamamos de senso de perspectiva histórica" (2003b, p. 20).

O catolicismo de Freire nos servirá aqui, novamente, como ponte para esclarecer a importância da ação histórica, pois sua pedagogia pode ser lida 
a partir da tríade que fundamentou a Ação Católica: ver, julgar, agir. A essa tríade corresponde (1) o aprendizado da realidade histórica em que se vive, (2) a reflexão crítica sobre essa mesma realidade e (3) a ação sobre ela. Era preciso, pois, tornar-se sujeito da trama histórica, num processo geral que pode ser condensado no conceito de "conscientização". ${ }^{16}$

Alguém dotado do "senso de perspectiva histórica" é capaz de ver quais são os assuntos de maior importância na vida nacional e, emergindo consciente e criticamente dessa realidade, vê a si mesmo como um dos responsáveis por ela. A preocupação de Freire com o incentivo ao processo de "leitura do mundo" é resultado de seu "senso de perspectiva histórica", pois foi capaz de compreender a "antinomia fundamental" que impedia o desenvolvimento da sociedade brasileira.

Porém, para ser capaz de ver a realidade em que está imerso (correspondendo a uma "consciência ingênua"), o homem deve primeiro distanciar-se dela para conseguir tomá-la como objeto de conhecimento (1980, p. 26). Constata-se aqui como o princípio lógico e cronológico do conhecimento do mundo apresenta semelhança surpreendente com a construção feita por Weber (a renúncia) e por Dumont (o indivíduo fora do mundo) a partir do caso empírico indiano. Além disso, esses autores comentam o potencial de conhecimento adquirido nessa atitude, seja para ensinar aos demais que permanecem no mundo, seja para se tornar um "indivíduo-no-mundo" (Dumont), isto é, na linguagem de Paulo Freire, emergindo da realidade em que estava preso, ingenuamente. Não podemos esquecer, na perspectiva cristã, da Quaresma como período em que Jesus se afasta do mundo, se retira para o deserto; é o momento litúrgico em que o católico deve realizar sua penitência, refletir sobre o mundo em que vive e preparar-se para a Páscoa - que significa "passagem".

Este processo de passagem de consciência ingênua para crítica é, de fato, como vimos, uma conversão e um renascimento em uma nova vida - e é resultado de uma anunciação/evangelização. ${ }^{17}$ A possibilidade de ver a realidade depende de um abandono da vida no mundo, tal como acontecia anteriormente, e o renascimento em uma nova vida. A "passagem" de uma a outra é somente o pri- meiro passo no processo de libertação. ${ }^{18}$ Sugiro que seja esse o sentido da afirmação de Freire: "No fundo, tem de viver a profunda significação da Páscoa” (Freire, 1979a, p. 93).

Após ter sido capaz de ver o momento histórico e o contexto social no qual estava imerso, o educando atingirá o segundo passo do processo: julgar, ou, nas palavras de Freire, trata-se da assunção de uma reflexão crítica sobre esse contexto histórico-social.

Até o início dos anos de 1960, Freire não havia adotado a postura marxista (ou o "cristianismo da libertação") que o tornou famoso após a publicação de Pedagogia do oprimido. ${ }^{19}$ Sua primeira posição político-ideológica era nacional-desenvolvimentista, na linha dos intelectuais do Iseb, isto é, uma busca por conciliação entre as diferentes classes sociais que se beneficiariam mutuamente de um desenvolvimento econômico nacional que substituísse a importação e a submissão ao capitalismo estrangeiro (Paiva, 1980).

No campo das teorias educacionais, Freire se detinha nos questionamentos sobre a educação "verborrágica", incapaz de responder às demandas concretas da realidade histórica. Anísio Teixeira afirmava a necessidade de ensino em diversos níveis, como o ensino técnico e a formação do trabalhador para a indústria: ${ }^{20}$

[...] a educação ajustada às condições culturais brasileiras se fará autêntica e verdadeira, identificando-se com o país e ajudando a melhor descobri-lo, para cooperar, como lhe cabe, na grande tarefa de construção da cultura brasileira (Teixeira, [1953] 1994, p. 73).

A industrialização e o consequente desenvolvimento nacional seriam benéficos para todas as classes sociais, diminuindo progressivamente a injustiça social. Mas, para que isso ocorresse, todos precisavam integrar-se no processo de desenvolvimento, isto é, precisavam compreender a situação histórica em que viviam e comprometer-se com ela, integrando-se autenticamente ${ }^{21}$ no desenvolvimento nacional (Paiva, 1980, p. 79).

A posição de Freire alterou-se nos seus últimos momentos passados no Brasil. Preso após o golpe 
de abril de 1964, ele radicaliza sua proposta. Para ele agora o julgamento correto da realidade seria a contraposição ao capitalismo desumanizante, e essa visão já está presente em Educação como prática da liberdade, de 1965.

Quanto ao terceiro passo - agir -, Freire se dava conta de que não bastaria ter uma clara consciência dos fenômenos se ela não se transformasse em ação (1977, p. 106). E, para ele, a participação popular não deveria ocorrer na forma da "algazarra”, mas ser fruto do aprendizado do diálogo: o desejo é por uma escola "que não apenas ajude a nossa democratização, mas também evite perigos contidos no próprio ímpeto de participação popular" (2003b, p. 97).

A ação compreende, pois, dois fenômenos: o voto democrático e a presença no mundo. O primeiro é a maneira adequada de exercer o poder político, o que envolve a análise da conjuntura e a escolha do candidato que apoia o desenvolvimento nacional; o segundo abrange a relação entre os homens, ao tornar concreto no meio social os princípios e os valores democráticos introjetados. Nesse sentido, o diálogo é fundamental, assim como a humildade e a responsabilidade por seus atos; em suma, o autogoverno. É importante ressaltar que, para Freire, a democracia não era apenas uma forma de governo, mas, sobretudo, uma "forma de vida" (Idem, p. 82) com suas "disposições mentais" correspondentes.

\section{Conclusão}

A interpretação do Brasil proposta por Freire é, no fundo, um diagnóstico de seu tempo presente. Com base em sua trajetória pessoal, transformou sua experiência em discurso ativo, envolvendo-se na tarefa pública e teórica de modificar o cenário brasileiro de então. O diagnóstico serviu, portanto, a uma programática, qual seja, a conscientização como desenvolvimento de um novo sujeito nacional, uma nova "disposição mental" para o povo brasileiro.

Essa concepção de conscientização proposta por Paulo Freire é provavelmente, hoje, a estratégia política revolucionária por excelência da esquerda católica na América Latina. Nascida de um católico, ela tem grande apelo nos meios católicos. O humanismo cristão que a inspira, seu caráter ao mesmo tempo neutro e ideológico, sua ênfase na liberdade e na responsabilidade, seu claro relacionamento com a "conversão", a prioridade que dá à mudança de mentalidade ao invés da mudança das estruturas. Todos esses aspectos têm um forte apelo para os católicos e ajudam-nos a explicar a adoção da conscientização como sua estratégia básica" (Bresser-Pereira, 2006, p. 128). ${ }^{22}$

Bresser-Pereira, contudo, não ponderou nesta passagem que, além da ideia de conversão, há uma relação explícita com o testemunho. Sublinhei, portanto, o que parece ser um aspecto distintivo desta forma narrativa: mais do que a transmissão da experiência (Benjamin, 1994a), que deve ser pessoal, almeja-se uma fala performativa capaz de replicar a experiência inicial no ouvinte. Evidentemente, há critérios capazes de tornar essa prática eficaz, como um solo comum e um universo de semelhança entre emissor e receptor do discurso. $\mathrm{Na}$ narrativa de Freire, a pobreza e a opressão consubstanciam tal universo na sociedade brasileira. Ao apontar como uma das origens do fatalismo o compartilhamento da condição histórico-social, Freire generaliza a experiência que antes estava restrita à sua singularidade existencial. De fato, a pobreza na infância, a fome e as dificuldades enfrentadas não são um caso excepcional, mas a regra, a experiência que permite que grande parte da população se reconheça na narrativa do testemunho. Ademais, o aspecto cristão presente também na origem do fatalismo é amplamente difundido. Por meio dessa abordagem, a pedagogia de Freire sugere, na esteira da Ação Católica, a transformação da relação dos cristãos com o próprio cristianismo, o que envolve uma ação ritualizada capaz de transformar o sujeito a quem se reporta para que ele seja um agente da transformação social.

A intenção deste texto não é comprovar as fundamentaçōes católicas do pensamento de Paulo Freire, nem realizar uma exegese para desvelar a realidade oculta por trás de sua pedagogia "crítica" e "progressista". Propus-me apontar como sua pro- 
posta pedagógica, situada no contexto imediatamente anterior e coetâneo ao Concílio Vaticano II, demonstra exemplarmente algumas das mudanças ocorridas no catolicismo brasileiro a partir do final deste período: a preocupação com a visão popular sobre Deus (como fonte de fatalismo), com a valorização da pessoa humana e com a transformação do mundo por meio da presença, conduzindo um processo de mundanização. ${ }^{23}$

É importante apreendermos esse processo por meio de um sujeito que não se reconhecia como teólogo nem como sacerdote. Ao analisar a vida e a obra de um dos mais importantes educadores de nosso país, ressalto a importância dos leigos neste processo, ao mesmo tempo que ocorre um visível esmaecimento nas fronteiras que circunscrevem o que é ou pode ser entendido como religiāo. Trata-se de um leigo que, de fato, produziu uma teoria "religiosa" e, ao mesmo tempo, uma pedagogia que pode ser considerada não "religiosa", isto é, uma pedagogia crítica e política. Esse apontamento tem em vista a necessidade de uma análise que leve em consideração a situação histórico-social em que o discurso é produzido antes de defini-lo, ou negá-lo, como religião (Asad, 2010; Arendt, 1994). Abordar tais termos como oposição não é, a meu ver, uma análise adequada; é necessário observar mais além da dicotomia religioso/secular e atentarmo-nos para como alguns agentes produzem, simultaneamente, secularidade e religião.

Nesse sentido, sua ação pública, em consonância com a militância católica do período, é um processo de engajamento e de denúncia da ordem social injusta (fundamentado na autoridade máxima do papa João XXIII, em suas encíclicas Mater et Magistra e Pacem in Terris, de 1959 e 1963 respectivamente). Freire assume sua parcela de responsabilidade na busca pela humanização do mundo e dos homens. Suas formulações foram importantes desde então, marcando não apenas a pedagogia brasileira, latino-americana e mundial, como também a própria história da esquerda latino-americana, sobretudo por sua vinculação com os teólogos católicos da Libertação (Löwy, 2000, pp. 136-140). Mas isso já é (outra) história.

\section{Notas}

1 O termo "mundanização", embora não seja comum em português, é uma das traduções possíveis para o original alemão Verweltlichung utilizado por Hegel (além de Feuerbach e Marx) e, frequentemente, traduzido por "secularização", tal como Säkularisierung. Cf. Marramao (1997, pp. 25 ss.) e Monod (2002, pp. 11 ss.).

2 Não vejo o livro como uma autobiografia e sim um texto com alto teor testemunhal, com características do gênero latino-americano traçadas por Seligmann-Silva (2005, pp. 89-91).

3 Para uma discussão sobre a dimensão testemunhal nas Confissões, ver Pierron (1995).

4 O trabalho de Castro Faria sobre Oliveira Vianna foi muito inspirador para a elaboração deste texto, inclusive por ecoar inquietações minhas a partir de leitura sistemática das reflexões de Foucault. O trecho, citado por Faria e que indiquei de Foucault é: "De fato, a única unidade que poderia ser reconhecida na 'obra' de um autor é certa função de expressão. Supõe-se que deve haver um nível (tão profundo que é necessário supô-lo) no qual a obra se revela, em todos os seus fragmentos, mesmo os mais minúsculos e os mais dispensáveis, como a expressão do pensamento, da experiência, da imaginação, do inconsciente do autor ou das determinaçôes históricas às quais ele estava preso. Mas logo se vê que essa unidade do opus, longe de ser dada imediatamente, é constituída por uma operação; que essa operação é interpretativa (no sentido de que ela decifra, no texto, a expressão ou a transcrição de alguma coisa que simultaneamente ela esconde e manifesta); que, enfim, a operação que determina o opus em sua unidade e, consequentemente, a própria obra como resultado dessa operação não serão as mesmas, quer se trate do autor do Thêatre et son double ou do autor de Tractatus" (Foucault, 2000, p. 90)

5 Pesquisei a sua biblioteca particular no Instituto Paulo Freire. As obras do período formativo que permaneceram são valiosas por conterem grifos e anotações, além de datas de aquisição/leitura.

6 Para a importância da Carta de dom Leme, ver Villaça (1975, pp. 78-86).

7 Para uma aproximação à trajetória de Figueiredo, ver Pinheiro Filho (2007).

8 Para uma análise detida da revista até 1948 , ver Crochet (2003).

9 Quando a Juventude Universitária Católica (JUC) 
se estabeleceu no Recife, no início dos anos de 1950, Freire não era mais estudante, pois se graduara em Direito em 1947. Porém, como a Ação Católica não era um movimento restrito aos jovens, é visível a sua importância.

10 "É praticamente unânime o consenso que considera a JUC como o 'epicentro' das mudanças mais significativas que foram empunhadas como bandeira por todo o movimento de esquerda católica no início dos anos 60" (Semeraro, 1991, p. 17).

11 As citações foram tiradas da tese de 1959, Educação e atualidade brasileira (Freire 2003b), apesar de ser possível encontrar o mesmo percurso explicativo em seu primeiro livro, Educação como prática da liberdade, que é uma reescrita da tese para publicação em 1965. A diferença é que o golpe militar de 1964 adentra o fim do capítulo histórico-social do livro como comprovação da força do "ontem" em se perpetuar para evitar a "emersão do povo na vida democrática".

12 Sua análise inclui informaçôes retiradas de livros de cronistas e viajantes, além de religiosos, sobre os quais não será possível deter-me neste momento. São eles: Saint-Hilaire, John Luccock, João André Antonil, Ina Von Binzer, João Maurício Rugendas, Manuel da Nóbrega, Maria Graham e Daniel Kider.

13 É importante notar que Gilberto Freyre, além de conterrâneo, era também colega de Paulo Freire, pois ambos eram professores na Escola de Belas-Artes de Pernambuco, para a qual a tese de 1959 foi escrita num concurso para a cadeira de História e Filosofia da Educação.

14 Segundo Freire, seu conceito de "dialogação" baseou-se no conceito de "parlamentarização" do isebiano Guerreiro Ramos.

15 Quando Freire era aluno na Faculdade de Direito de Recife, ocorreu um atentado contra a vida de Gilberto Freyre durante um evento dos alunos. A repercussão foi enorme, principalmente após as medidas autoritárias do interventor de Vargas. Os jornais da época noticiavam ferozmente contra as censuras impostas à imprensa, sendo que a coluna de Assis Chateaubriand no Diário de Pernambuco de 10 de Abril de 1945 afirmava: "No primeiro round, a democracia em Pernambuco está 0 a 1 . O ministro da Justiça mandou mostrar àquela gente o que são essas frioleiras de urnas, de democracia e instituições populares. $\mathrm{O}$ espectro do fascismo se levanta nas ruas do Recife, tendo como encarnações o rebutalho da sua sociedade, que é chamado para governá-la à cossaca, de garrucha na calça e fechamento da imprensa livre por ordem, não do poder federal, mas dos bandidos que ali se sobrepõem à autoridade do Sr. Getúlio Vargas".

16 Cabe sublinhar que Freire atribui a criação do termo aos intelectuais do Iseb, especialmente Álvaro Vieira Pinto e Guerreiro Ramos, e sua difusão em outras línguas por dom Hélder Câmara (Freire, 1980, p. 25).

17 " $[. .$.$] o educador para a libertação tem de 'morrer' en-$ quanto exclusivo educador dos educandos no sentido de renascer, no processo, como educador-educando dos educandos. Por outro lado, tem de propor aos educandos que também 'morram' enquanto exclusivos educandos do educador para que renasçam como educandos-educadores do educador-educando. Sem esta morte mútua e sem este mútuo renascimento a educação para a libertação é impossível" (Freire, 1979a, p. 92).

18 É importante ressaltar que a Teologia da Libertação faz uma leitura da Bíblia tendo como epicentro o Êxodo dos judeus do domínio egípcio, período também compreendido como Páscoa.

19 Redigido em 1968, este livro foi publicado primeiramente em inglês em 1970, depois de Freire passar uma temporada em Harvard como professor-visitante; no Brasil só veio a ser publicado em 1974.

20 "A educação para o desenvolvimento, a educação para o trabalho, a educação para produzir substituirá a educação para a ilustração, para o ornamento e, no melhor dos casos, para o lazer" (Teixeira, [1953] 1994, p. 73).

21 O conceito de "autenticidade" é temporal e compreende esse processo de integração na realidade histórica. Paulo Freire incorporou tal visão a partir dos trabalhos do Iseb e da filosofia de Karl Jaspers, incluindo a tradução deste autor para o português feita pelo isebiano Alvaro Vieira Pinto. Como afirma Vanilda Paiva, citando Hélio Jaguaribe em livro citado por Freire, este conceito, "tomado à filosofia da existência, insere-se num quadro culturalista: 'São autênticas as ideologias que [...] formulem para a comunidade critérios e diretrizes que a encaminhem no sentido de seu processo faseológico, ou seja, que permitam o melhor aproveitamento das condiçōes naturais da comunidade, em função dos valores predominantes na civilização a que pertence'. Em suma, a 'adequação à fase' é elevada a critério de autenticidade: as ideologias como 'conjunto de valores e de ideias' que se subordinam a um sistema cultural e sobre as quais influem as particularidades das situações, são autênticas (ou seja, ficam legitimadas em seu papel de comandar o comportamento social da comunidade) na medida em que 
servem à fase ou à 'transição de fase' atravessada pela comunidade" (Paiva, 1980, p. 40).

22 Em contrapartida, Bresser-Pereira afirma que o pensamento e a práxis de Paulo Freire estavam demasiadamente colados ao idealismo e ao reformismo católico e não somente às posturas revolucionárias. Entretanto, sua tese central vai contra os princípios de minha análise, ao postular a religião como uma "necessidade" e uma resposta, cabendo-lhe uma função social: "Defenderemos, então, uma tese básica: a de que a Igreja vem se transformando porque, de um lado, foi desertada pelas elites, que dela não mais necessitam tanto para sacralizar a ordem estabelecida, e de outro porque começou a ser abandonada pelas classes populares, que passavam a encontrar em outras religiões uma resposta mais direta a suas necessidades" (Bresser-Pereira, 2006, p. 109).

23 Para uma discussão pormenorizada das transformações do catolicismo no período e da corrente que levou a uma maior "mundanização", ver Dullo (2013).

\section{BIBLIOGRAFIA}

ARAÚJO, Ricardo Benzaquen de. (1994), Guerra e paz: Casa Grande \& Senzala e a obra de Gilberto Freyre nos anos 30. São Paulo, Editora 34. ARENDT, Hannah. (1989), A condição humana. 4. ed. Rio de Janeiro, Forense Universitária. . (1994), "Religion and politics", in , Essays in understanding: 19301954. Organizado por Jerome Kohn. Nova York, Schocken Books . (2008), "Agostinho e o protestantismo", in Compreender: formação, exílio e totalitarismo (1930-1954). São Paulo/ Belo Horizonte, Companhia das Letras/Editora UFMG.

ASAD, Talal. (2010), "A construção da religião como uma categoria antropológica". Cadernos de Campo, 19: 263-284.

AZZI, Riolando. (2008), História da Igreja no Brasil: ensaio de interpretação a partir do povo. Tomo II/3-2: Terceira época: 1930-1964. Petrópolis, Vozes.

BENJAMIN, Walter. (1994a), "O narrador: considerações sobre a obra de Nicolai Leskov", in , Magia e técnica, arte e política: en- saios sobre literatura e história da cultura. 7. ed. São Paulo, Brasiliense.

. (1994b), "Sobre o conceito de história”. in Magia e técnica, arte e politica: ensaios sobre literatura e história da cultura. 7. ed. São Paulo, Brasiliense.

BOTELHO, André. (2008), "Uma sociedade em movimento e sua intelligentsia: apresentação", in André Botelho, Elide Rugai Bastos e Glaucia Villas Bôas (orgs.), O moderno em questão: a década de 1950 no Brasil. Rio de Janeiro, Topbooks.

BRESSER-PEREIRA, Luiz Carlos. (2006), As revoluções utópicas dos anos 60: a revolução estudantil e a revolução política na Igreja. São Paulo, Editora 34.

CASANOVA, José. (2011), “The secular, secularizations, secularisms", in Craig Calhoun, Mark Juergensmeyer e Jonathan Van Antwerpen (orgs.), Rethinking secularism, Nova York, Oxford University Press

COSTA, Marcelo Timotheo da. (2001), "História, fé e exemplaridade: pensando o trajeto de $\mathrm{Al}$ ceu Amoroso Lima”. Alceu, 2 (3): 132-145.

CROCHET, Eduardo José. (2003), A Revista A Ordem e o pensamento católico no Brasil (19211948). Rio de Janeiro, mestrado em história social, Universidade Federal do Rio de Janeiro.

DULLO, Eduardo. (2012), "Após a (sociologia/antropologia da) religião, o secularismo?”. Mana, 18 (2): 379-392.

. (2013), A produção de subjetividades democráticas e a formação do secular no Brasil a partir da pedagogia de Paulo Freire. Rio de Janeiro, tese de doutorado em antropologia social, Universidade Federal do Rio de Janeiro, PPGAS - Museu Nacional.

DUMONT, Louis. (1985), O individualismo: uma perspectiva antropológica da ideologia moderna. Rio de Janeiro, Rocco.

FARIA, Luiz de Castro. (2002), Oliveira Vianna: de Saquarema à alameda São Boaventura, 41 Niterói: o autor, os livros, a obra. Rio de Janeiro, Relume-Dumará/Nuap/UFRJ.

FOUCAULT, Michel. (2000), "Sobre a arqueologia das ciências: resposta ao círculo de epistemologia", in , Arqueologia das ciên- 
cias e história dos sistemas de pensamento. Rio de Janeiro, Forense Universitária

FREIRE, Paulo. (1977), Educação como prática da liberdade. 7. ed. Rio de Janeiro, Paz e Terra.

(1979a), "O papel educativo das igrejas na América Latina”, in Ação cultural para a liberdade e outros escritos. 4. ed. Rio de Janeiro, Paz e Terra.

- (1979b), "O processo de alfabetização política: uma introdução" , in Ação cultural para a liberdade e outros escritos. 4. ed. Rio de Janeiro, Paz e Terra.

. (1980), Conscientização: teoria e prática da libertação: uma introdução ao pensamento de Paulo Freire. 3. ed. São Paulo, Moraes.

. (2001), "Algumas reflexōes em torno da utopia", in , Pedagogia dos sonhos possiveis. 3. reimp. São Paulo, Editora da Unesp.

. (2003a), Cartas a Cristina: reflexôes sobre minha vida e minha práxis. 2. ed. São Paulo, Editora da Unesp. (2003b), Educação e atualidade brasileira. 3. ed. São Paulo, Cortez/Instituto Paulo Freire.

. (2005), Pedagogia do oprimido. 49. reimp. Rio de Janeiro, Paz e Terra.

KADT, Emanuel de. (2003), Católicos radicais no Brasil. João Pessoa, Editora Universitária da UFPB.

LÖWY, Michael. (2000), A guerra dos deuses: religião e política na América Latina. Petrópolis, Vozes.

MARRAMAO, Giacomo. (1997), Céu e terra: genealogia da secularização. São Paulo, Editora da Unesp.

MONOD, Jean-Claude. (2002), La querelle de la sécularisation: théologie politique et philosophies de l'histoire de Hegel à Blumenberg. Paris, Librarie Philosophique J. Vrin.

PAIVA, Angela. (2003), Católico, protestante, cidadão: uma comparação entre Brasil e Estados Unidos. Belo Horizonte/Rio de Janeiro, Editora UFMG/Iuperj.

PAIVA, Vanilda. (1980), Paulo Freire e o nacionalismo-desenvolvimentista. Rio de Janeiro, Civilização Brasileira.
PIERRON, Jean-Philippe. (1995), "La question du témoignage dans les Confessions de Saint Augustin”. Revue des Études Augustiniennes, 41: 253-266.

PINHEIRO FILHO, Fernando. (2007), "A invenção da ordem: intelectuais católicos no Brasil”. Tempo Social, 19 (1): 33-49.

RIDENTI, Marcelo. (2002), "Ação Popular: cristianismo e marxismo", in Daniel Aarão Reis Filho e Marcelo Ridenti (orgs.), História do marxismo no Brasil. Vol 5: Partidos e organizaçóes dos anos 20 aos 60, Campinas, Editora da Unicamp.

SELIGMANN-SILVA, Márcio. (2005), "Literatura, testemunho e tragédia: pensando algumas diferenças", in , O local da diferença: ensaios sobre memória, arte, literatura e tradução. São Paulo, Editora 34.

SEMERARO, Giovanni. (1991), A esquerda católica do Brasil: formação na prática político-educativa e no horizonte teórico dos anos 1959-1964. Rio de Janeiro, dissertação de mestrado em educação, Fundação Getúlio Vargas.

SOUZA, Jessie Jane Vieira de. (2002), Círculos operários: a igreja católica e o mundo do trabalho no Brasil. Rio de Janeiro, Editora da UFRJ.

TAYLOR, Charles. (2007), A secular age. Cambridge, Harvard University Press.

TEIXEIRA, Anísio. ([1953] 1994), Educação não é privilégio. 5. ed. Rio de Janeiro, Editora da UFRJ.

VILLAÇA, Antonio Carlos. (1975), O pensamento católico no Brasil. Rio de Janeiro, Zahar Editores.

WEBER, Max. (1982), "Rejeições religiosas do mundo e suas direções", in , Ensaios de sociologia. 5. ed. São Paulo, LTC. 


\section{PAULO FREIRE, O TESTEMUNHO \\ E A PEDAGOGIA CATÓLICA: A AÇÃO HISTÓRICA CONTRA O FATALISMO}

Eduardo Dullo

Palavras-chave: Paulo Freire; Catolicismo; Pensamento Social; Testemunho; Secularização.

O educador Paulo Freire apresenta duas fontes para o sentimento de fatalismo presente em nossa sociedade: a visão distorcida de Deus e o contexto histórico-social brasileiro. Com base nisso, ele realiza sua crítica social como denúncia do mundo injusto que impede a plena realização da pessoa humana e como anúncio e fomento de uma nova ordem social, desenvolvida e democrática. Para tanto, faz-se necessário promover no sujeito o senso histórico e a capacidade de ação no mundo. Em minha análise, discuto a fundamentação católica da sua proposta pedagógica da conscientização e de sua estratégia narrativa do testemunho como produtoras de mudança social e como exemplos da nova relação católica com o mundano.

\section{PAULO FREIRE, TESTIMONY AND CATHOLIC PEDAGOGY: HISTORICAL ACTION AGAINST FATALISM}

\section{Eduardo Dullo}

Keywords: Paulo Freire; Catholicism; Social Thought; Testimony; Secularization.

Paulo Freire states the existence of two sources for the sense of fatalism present in our society: the misguided view of God and the Brazilian social and historical context. Based on such conception, he develops his social critique as a condemnation of the unfair world that thwarts the full realization of the human person and as an announcement and encouragement of a new social order, developed and democratic. In order to achieve such goal, it is necessary to promote in the subject his historical sense and capacity of acting in the world. This article discusses the catholic foundation of Freire's pedagogy of 'conscientização' and of his narrative strategy of the testimony as producers of social change and examples of the new catholic relationship with the mundane.
PAULO FREIRE, LE TÉMOIGNAGE ET LA PÉDAGOGIE CATHOLIQUE: L'ACTION HISTORIQUE CONTRE LE FATALISME

\section{Eduardo Dullo}

Mots-clés: Paulo Freire; Catholicisme; Pensée Sociale; Témoignage; sécularisation.

L'éducateur Paulo Freire présente deux origines du sentiment de fatalisme présent dans notre société: la compréhension déformée de Dieu et le contexte historique et social brésilien. Il entreprend ainsi sa critique sociale en tant que dénonciation du monde injuste qui empêche la totale réalisation de l'être humain, mais aussi en tant quannonce et motivation diun nouvel ordre social, développé et démocratique. Il est, pour cela, nécessaire de promouvoir dans lindividu le sens historique et la capacité draction dans le monde. Mon analyse discute le fondement catholique de sa proposition pédagogique de conscientisation et de sa stratégie narrative du témoignage comme productrices de changements sociaux et exemples de la novelle relation entre le catholique et le mondain. 